\title{
COMPARATIVE STUDY ON THE BEHAVIOR OF CONVENTIONAL FERROCEMENT AND MODIFIED FERROCEMENT WRAPPED COLUMNS
}

\author{
V Anandan \\ Department of Civil Engineering, \\ Periyar Maniammai Institute of Science and Technology, Thanjavur, Tamil Nadu, India.

\section{S Senthamilkumar} \\ Department of Civil Engineering, \\ Periyar Maniammai Institute of Science and Technology, Thanjavur, Tamil Nadu, India.

\section{Sundararajulu} \\ Department of Civil Engineering, \\ Periyar Maniammai Institute of Science and Technology, Thanjavur, Tamil Nadu, India.

\section{S Gunaselvi} \\ Department of Civil Engineering, \\ Valliammai Engineering College, Chennai, Tamilnadu, India.
}

\section{Jeganathan}

Department of Environmental Science, Prime Nest College of Architecture and Planning, Siruganur, Thiruchirappalli, Tamilnadu, India

\begin{abstract}
This paper presents results of an experimental study on the increase in the load carrying capacity of conventional ferrocement wrapped columns and modified ferrocement columns. In this study a ferrocement wrapping reinforced with 2 layers of welded steel meshes is used. Six short RCC square columns including four strengthened columns (Two with conventional ferrocement and two with modified ferrocement) were tested. The specimen were subjected to axial compressive load till failure. The results indicated that the increase in load carrying capacity of Column wrapped with conventional ferrocement is about $79.60 \%$ over control specimen that of column wrapped with modified ferrocement is about $89.80 \%$ over control specimen. Hence it is concluded that modified ferrocement jackets can be effectively used for strengthening of columns.
\end{abstract}

Keywords: Conventional Ferrocement, Modified Ferrocement and Wrapped Columns. 
Cite this Article: V Anandan, S Senthamilkumar, V Sundararajulu, S Gunaselvi and M Jeganathan, Comparative Study on the Behavior of Conventional Ferrocement and Modified Ferrocement Wrapped Columns, International Journal of Advanced Research in Engineering and Technology, 10 (6), 2019, pp 22-29.

http://iaeme.com/Home/issue/IJARET?Volume=10\&Issue $=6$

\section{INTRODUCTION}

Concrete is a common material used for construction of Buildings and other civil Engineering structures all over the world. It is likely for deterioration due to various factors such as earth quake, floods, over loading etc. Moreover most of the existing structures were designed according to old codal provisions and design procedures. Column is the most important structural element which is designed to support mainly the compressive loads (Hasan, et.al., 2011). Failure of building columns lead to failure of a building, as only through that element, vertical loads are transferred to the ground(Kaish and Kamrul, 2008). Hence it is important to develop an effective technique to strengthen and retrofit the deteriorated columns. The method is to be structurally effective and cost effective. Jacketing/wrapping of concrete columns with a suitable material for strengthening can be a better option. Reinforced Concrete, steel plates, fiber reinforced polymers, FRP composites are the commonly used strengthening techniques. Each technique has some advantages and disadvantages. There may be some limitation in all the above techniques for field applications. Reinforced concrete columns can be effectively strengthened using ferrocement wrapping because of its adaptability, high strength to weight ratio, good cracking characteristics, and good bond with existing concrete when compared to other strengthening materials.

Fiber Reinforced Polymers is extensively used nowadays for strengthening of concrete members. But FRP is very expensive and its installation also requires skilled labors. Providing FRP installation in hot and humid climate is very difficult and requires special arrangement. Ferrocement, on the other hand is cost effective. The raw materials used for ferrocement is easily available locally in developing countries. Ferrocement is a type of thin wall reinforced concrete commonly constructed of hydraulic cement mortar reinforced with closely spaced layers of continuous and relatively small size wire mesh. The mesh may be made of metallic or other suitable materials. The fineness of the mortar matrix and its composition should be compatible with the mesh and armature systems it is meant to encapsulate. The matrix may contain discontinuous fibers.

In its role as thin reinforced concrete product and as laminated cement based composite, ferrocement can be used in numerous applications, including new structures and the repair and rehabilitation of existing structures. Although ferrocement is an old technology, it is widely used as a construction material with modern technology in developed and developing countries. It is one of the cost effective materials for strengthening of concrete columns due to its improved structural properties.

Many researchers have recommended ferrocement as the wrapping material for strengthening of concrete columns. Sandowich and Grabowski, (1981) have studied both axial and eccentric load behavior of circular composite columns made of ferrocement pipes filled concrete column and reported a ductile behavior of such columns. Singh and Kaushik, (1988) studied the effectiveness of ferrocement confinement for repairing both circular and square short columns and achieved an enhanced strength and ductility of the jacketed specimens. Mourad, (1992) investigated the behavior of externally confined plain concrete with welded wire mesh ferrocement. He studied the effect of different attaching methods of wire mesh around the concrete specimen. Kondraivendhan and Pradhan, (2009) have investigated the 
behavior of ferrocement confined cylindrical concrete specimens of different grades and observed that the strength enhancement varies with grade of concrete. Xiong et al., (2011) investigated the strength and ductility of plain concrete encased with ferrocement including skeletal steel bars and compared with FRP confined concrete. They concluded that the ferrocement cofined concrete is more ductile under axial load than that of FRP confined concrete. Amrul Kaish et al.(2013) proposed some improved square ferrocement jacketing to strengthen square RC columns. The performance of those improved square ferrocement jacketed square RC columns under concentric compressive load was verified later by Amrul Kaish et al., (2013) have also investigated the behavior of ferrocement encased square RC columns under eccentric load. Ho et al., (2013) have proposed a strengthening method of circular RC columns using high performance ferrocement composites.

From the above ferrocement is considered as an effective material for strengthening of axially loaded columns due to the following:

- Ferrocement is homogeneous and isotropic in two directions.

- Ferrocement has good tensile strength and high specific surface area of reinforcement

- Ferrocement has better extensibility, smaller crack width, higher durability to environmental exposure etc.

- Cost effective

- Local labours can be employed for ferrocement construction

- Very high quality control

- Light in weight

- Environmental friendly

- Easy production

This study is intended to compare the additional load carrying capacity of the reinforced concrete columns strengthened with conventional ferrocement wrapping and modified ferrocement wrapping.

\section{METHODOLOGY}

The experimental study was carried out on 6 concrete columns. The size of specimen was 150x $150 \times 700 \mathrm{~mm}$. The columns were provided with four $12 \mathrm{~mm}$ dia rods as reinforcement and $8 \mathrm{~mm}$ dia lateral ties at $100 \mathrm{~mm}$ centre to centre spacing. Out of these 6 columns, two specimens were control specimen. Two columns were wrapped with conventional ferrocement and the remaining two were wrapped with modified ferrocement. The ferrocement wrapping consisting of two layers of welded wire mesh. The thickness of ferrocement wrap was kept at $25 \mathrm{~mm}$ for the wrapped specimens of both the types.

\section{MATERIALS AND METHODS}

\subsection{Cement}

Ordinary Portland cement 53 grade conforming to Indian standards (IS-12269, 1987) is used throughout. The standard consistency is $29 \%$ and its initial and final setting time is $50 \mathrm{~min}$ and 250 min respectively. The specific gravity of cement is 3.14 and its compressive strength after 28 days of curing is $54 \mathrm{~N} / \mathrm{Sqmm}$. 
Comparative Study on the Behavior of Conventional Ferrocement and Modified Ferrocement Wrapped Columns

\subsection{Coarse Aggregate}

Crushed hard granite stone aggregate of maximum size $20 \mathrm{~mm}$ is used for concrete. The bulk density of aggregate is $16.90 \mathrm{KN} / \mathrm{Cum}$ and its specific gravity is 2.64 .

\subsection{Fine Aggregate}

Fine aggregate used is river sand conforming to Zone-II of IS: 383, 1970. The fineness modulus is 2.61 . Its specific gravity is 2.69 and its dry density is $16.05 \mathrm{KN} / \mathrm{Cum}$.

\subsection{Water}

Potable water is used for casting as well as curing as per IS: 456/2000.

\subsection{Super Plasticizer}

To achieve strength and workable mortar, super plasticizer CONPLAST SP-337 of FOSROC is used.

\subsection{Wire Meshes}

Galvanized steel welded wire meshes are used. The diameter of wire mesh is $0.6 \mathrm{~mm}$ and size of mesh is $12 \mathrm{~mm} \times 12 \mathrm{~mm}$ and its yield strength is $250 \mathrm{~N} / \mathrm{Sqmm}$.

\subsection{Reinforcement}

$8 \mathrm{~mm}, 12 \mathrm{~mm}$ diameter TMT bars are used in columns. Steel grade $=415 \mathrm{~N} / \mathrm{Sqmm}$

\subsubsection{The fly ash of following mass composition was used for this investigation.}

- $\mathrm{SiO} 2-53.39 \%$

- $\mathrm{A} 12 \mathrm{O} 3-26.45 \%$

- $\mathrm{Fe} 2 \mathrm{O} 3-11.19 \%$

- $\mathrm{CaO}-1.39 \%$

- $\mathrm{Na} 2 \mathrm{O}-0.35 \%$

- $\mathrm{K} 2 \mathrm{O}-0.93 \%$

- $\mathrm{TiO} 2-1.46 \%$

- $\mathrm{P} 2 \mathrm{O} 5-1.47 \%$

- $\mathrm{SO} 3-1.77 \%$

\subsection{Silica fume}

Silicafume a byproduct of producing silicon metal.

- $\quad$ Silicon Dioxide $>85 \%$

- $\mathrm{CaO}<1$

- $\quad$ Sp surface area $=22000 \mathrm{Sqm} / \mathrm{kg}$

- $\quad$ Sp Gravity $=2.2$

- Particle size $=$ one micrometer 
The Concrete mix comprised cement $400 \mathrm{Kg} / \mathrm{cum}$, water $200 \mathrm{Ltr} / \mathrm{cum}$, sand $640 \mathrm{~kg} / \mathrm{Cum}$ and Stone aggregate $1200 \mathrm{~kg} / \mathrm{cum}$. The average compressive strength of $150 \times 150 \times 150 \mathrm{~mm}$ standard concrete cubes after 28 days of curing was $22.05 \mathrm{~N} / \mathrm{Sqmm}$.

\subsection{Ferrocement (Conventional)}

The ferrocement of fresh matrix was cast with cement to sand ratio was 1:2 and the water cement ratio $0.40 .2 \%$ super plasticizer by weight of cement was also added.

\subsection{High Strength Ferrocement (Modified)}

The ferrocement of fresh matrix was cast with cement to sand ratio was 1:2 with silica fume $10 \%$ by weight of cement ; $10 \%$ by weight of fly ash and the water cement ratio $0.40 .3 \%$ super plasticizer by weight of cement was also added. (Mourad and Shannag,2012).

\subsection{Preparation of specimens}

The Column specimens were prepared according to the following procedure.

\subsection{Reinforcement}

Four vertical bars of $12 \mathrm{~mm}$ diameter were used as vertical reinforcement. $8 \mathrm{~mm}$ diameter lateral ties were provided at $150 \mathrm{~mm}$ centre to centre. The clear cover provided was $25 \mathrm{~mm}$.

\subsection{Timber Formwork}

Timber form work of size $150 \times 150 \times 700 \mathrm{~mm}$ were designed and fabricated to cast the columns in vertical position. The formwork can be easily assembled and separated to parts. The form work was made of $150 \times 20 \mathrm{~mm}$ wooden pieces. Three sides were assembled in horizontal position, the fabricated reinforcement cage was carefully placed in the formwork and the fourth side was fixed in position and then stiffeners were added and the fourth side was turned in vertical position.

\subsection{Mixing and Casting of Concrete Columns}

The concrete was mixed manually with the specified ratios given in section 2.2. The fresh concrete was transferred to the formwork in position and was poured vertically. Concrete was consolidated by vibrator to provide concrete without voids or honeycomb. All the column specimens were demoulded after 24 hours of casting and were cured under moist sacking for 28 days.

\subsection{Reinforced Columns Strengthened with Ferrocement Jacketing}

After 28 days of curing four reinforced columns were strengthened using ferrocement wrapping, two with conventional ferrocement and other two with modified ferrocement.

The Concrete columns were painted with bonding agent. This was to fill the micro cracks on the concrete surface and to act as a bonding agent between the concrete and ferrocement.

The ferrocement (conventional) of fresh matrix was cast with cement to sand ratio was 1:2 and the water cement ratio $0.40 .2 \%$ super plasticizer by weight of cement was also added.

The modified ferrocement of fresh matrix was cast with cement to sand ratio was 1:2 with silica fume $10 \%$ by weight of cement ; $10 \%$ by weight of fly ash and the water cement ratio $0.40 .3 \%$ super plasticizer by weight of cement was also added.

After completion of 30 minutes of painting of columns, two layers of the welded wire mesh wrapped over the columns. Concrete spacers of $12 \mathrm{~mm}$ thick were used to maintain the cover. Then a steel trowel was used and force applied to ensure full penetration of matrix of 
conventional ferrocement in to the mesh. The final dimensions of the finished columns were $200 \mathrm{x} 200 \mathrm{~mm}$. A steel float was used to make the surface flat. The same procedure was adopted for wrapping the remaining two columns with modified ferrocement. The strengthened Columns were cured for 28 days.

\subsection{Testing of Columns}

Experimental results of the test specimen are discussed in After 28 days of curing, all the columns were tested under monotonically increasing concentrated load applied at the top with a hydraulic compression testing machine of $2000 \mathrm{KN}$ capacity. Both the reference columns and ferrocement wrapped columns were tested to failure. Axial deflection and lateral buckling of columns were measured using dial gauges.

\section{RESULTS AND DISCUSSION}

All the four ferrocement wrapped columns show higher ultimate load carrying capacity than the reference/control columns. The column specimen wrapped with normal (conventional) ferrocement show an average of $78.97 \%$ increase in ultimate load carrying capacity over reference columns. Columns wrapped with modified (high strength) ferrocement show an average of $87.51 \%$ increase in ultimate load carrying capacity over reference columns.

Typical failure pattern of tested columns are shown in Fig.1. The Control columns failed by crushing of concrete at the point of application of load. The ferrocement wrapped columns failed from ferrocement jacket.
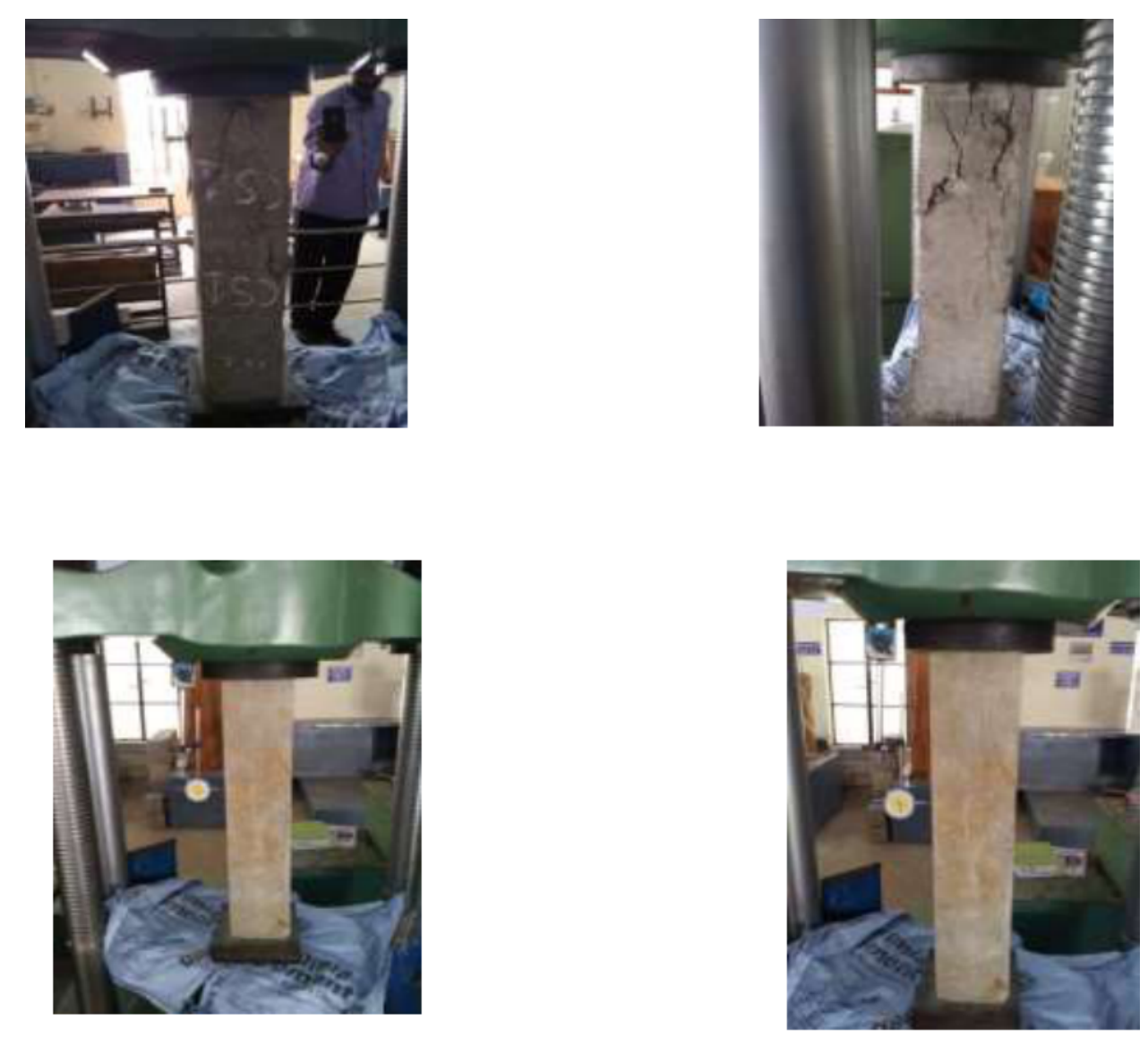

Figure 1. Typical failure pattern of tested columns 
Table 1. Typical failure pattern of tested columns

\begin{tabular}{|c|c|c|c|}
\hline SI No & Specimen Type & $\begin{array}{c}\text { Ultimate Load } \\
\text { (KN) }\end{array}$ & $\begin{array}{c}\text { \% ge increase in } \\
\text { Ultimate Load }\end{array}$ \\
\hline A & Control specimen & & \\
\hline 1 & CS1 & 452 & 0.00 \\
\hline 2 & CS2 & 461 & 0.00 \\
\hline B & $\begin{array}{c}\text { Ferrocement wrapped Column } \\
\text { (Conventional Ferrocement) }\end{array}$ & 456.50 & \\
\hline 1 & FCC1 & 814 & 78.31 \\
\hline 2 & FCC2 & 820 & 79.63 \\
\hline C & $\begin{array}{c}\text { Ferrocement wrapped Column } \\
\text { (Modified High Strength } \\
\text { Ferrocement) }\end{array}$ & 817 & 78.97 \\
\hline 1 & MFCC1 & 852 & \\
\hline 2 & MFCC2 & 860 & 86.64 \\
\hline & Average & 856 & 87.51 \\
\hline
\end{tabular}

\section{CONCLUSION}

From the findings of this experimental investigation, the following conclusions are drawn:

- Ferrocement wrapping/jacketing (with normal ferrocement) increases the ultimate load carrying capacity to about $78.97 \%$ over the control columns.

- Modified ferrocement wrapping/jacketing (with high strength ferrocement) increases the ultimate load carrying capacity to about $87.51 \%$ over the control columns.

- Modified ferrocement wrapping can be used for strengthening and rehabilitation of structures effectively.

\section{REFERENCES}

[1] Amrul Kaish, A.B, M.R.Alam, M.Jamil and M.A.Wahed, Ferrocement jacketing for restrengthening of square reinforced concrete column under concentric compressive load, Procedia Engineering, 2013, 54, pp 720-728.

[2] Hassan, M.K, Alam, MR, Kaish, ABMA and MFM Zain, MFM, Effectiveness of Truss Supporting During Replacement of Damaged Column in a High-Rise Frame Structure Building, International Conference on Advanced Science, Engineering and Information Technology. (ICASEIT-2011), Selangor, Malaysia, 2011, pp 607-612.

[3] HO. I.F, Lam, E.S. Wu, B. Wang, Y, Monotonic behaviour of reinforcement concrete columns confined with high - performance ferrocement. Journal of structural engineering, 2013, 139 (4), pp 574-583.

[4] Kaish ABMA and HM Kamrul,HM, Retrofitting of high rise building components, B.Sc. Thesis, Department of Civil Engineering, Chittagong University of Engineering and Technology, Chittagong, Bangladesh, 2008

[5] Kondraivendhan B and Pradhan B, Effect of ferrocement confinement on behaviour of concrete. Construction and Building Materials, 2009, 23(3), pp 1218-1222.

[6] Mourad, S.M and Shannag, M.J, Repair and strengthening of reinforced concrete square columns using ferrocement jackets, Cement \& Concrete Composites, 2012, 34, pp 288-294.

[7] Murad Saatcioglu, Member and Salim R. Razvi, Strength and Ductility of Confined Concrete, Journal of Structural Engineering, 1992, 118 (6), pp 1590-1607. 
[8] Sandowich M and Grabowski J, The properties of composite columns made of ferrocement pipes filled with concrete tested in axial and eccentric compression. Bergamo, Italy: International Symposium on Ferrocement, 1981, 1981, pp 93-9.

[9] Dr. T.Ch.Madhavi, Shanmukha Kavya .V, Siddhartha Das, Sri Prashanth .V and Vetrivel .V, Composite Action of Ferrocement Slabs Under Static and Cyclic Loading, International Journal of Civil Engineering and Technology (IJCIET), 2013, Volume:4, Issue: 3, Pages: $57-$ 62.

[10] Singh, K.K. \& Kaushik, S.K, Ferrocement composite columns. Proceedings of the third International Conference on Ferrocement, Roorkee, India, 1988. 216-225.

[11] Dr. Samir Mohammed Chassib, Dr. Sa'ad Fahad Resan, Mohammad Salah Gejan, Murtadha Jabar Salih, Ali Mohsen Hasan, Developing Sustainable Lightweight Bubbled Ferrocement Slab Using Enhancing Cementitious Agents, International Journal of Civil Engineering and Technology (IJCIET) 9(11), 2018, pp. 749-765.

[12] Sidramappa Shivashankar Dharane, Archita Vijaykumar Malge, Earthquake Resistant Ferrocement Hallow Columns and Cavity Walls - New Concept, Volume 5, Issue 12, December (2014), pp. 292-295

[13] Sidramappa Shivashankar Dharane, Madhkar Ambadas Sul And Patil Raobahdur Yashwant, Earthquake Resistant Rcc And Ferrocement Cicular Columns With Main Spiral Reinforcement, International Journal of Civil Engineering and Technology (IJCIET), 2014, Volume:5,Issue:9,Pages:100-102.

[14] Xiong, G.J, X.Y.Wu, F.F.Li, Z.Yan. 2011. Load carrying capacity and ductility of circular concrete columns confined by ferrocement including steel bars, Construction and Building Materials, 2011, 25, pp 2263-2268.

[15] Mohammed Mansour Kadhum, Effect of Dynamic Load: Impact of Missile On Mechanical Behavior of Ferrocement - Infrastructure Application, International Journal of Civil Engineering and Technology (IJCIET), 2013, Volume: 4, Issue: 2, Pages: 295-305.

[16] Sidramappadharane and Architamalge, Experimental Performance of Flexural Behavior of Ferrocement Slab under Cyclic Loading, International Journal of Civil Engineering and Technology (IJCIET), 2014, Volume: 5, Issue: 3, Pages: 77-82.

[17] Dharane Sidramappa Shivashankar, Ferrocement Beams and Columns with X Shaped Shear Reinforcement and Tirrups, International Journal of Civil Engineering and Technology (IJCIET), 2014, Volume: 5, Issue: 7, Pages: 172-175.

[18] K. Sasiekalaa and R. Malathy, Flexural Performance Of Ferrocement Laminates Containing Silicafume and Fly Ash Reinforced With Chicken Mesh, International Journal of Civil Engineering and Technology (IJCIET), 2012, Volume:3,Issue:2,Pages:130-143. 